\title{
Trends and Policy Issues for the e-Learning Implementation in Libyan Universities
}

\author{
Thuraya Kenan, Crinela Pislaru, and Abdussalam Elzawi
}

\begin{abstract}
This paper provides an important snapshot of the current trends and policy issues for e-learning implementation in Libyan universities. The results of two Strength-WeaknessOpportunities-Threats (SWOT) models developed in 2009 and 2013 are compared and the evolution of e-learning implementation in Tripoli University is analysed. Several policy subjects and accessibility challenges related to the planning, development and implementation of e-learning strategies for undergraduate and postgraduate curricula are discussed. The paper also contains a set of suggestions to improve the learners' knowledge and understanding, recommendations for the institution regarding implementation of e-learning policies and governmental HE policies to evaluate, develop and approve e-learning business models or income revenue streams.
\end{abstract}

Index Terms-E-Learning implementation, e-learning strategy, Libyan universities, policy issues.

\section{INTRODUCTION}

The Libyan ICT infrastructure has been destroyed by the war in 2011, but many people (especially the youth) began to focus on social media and Internet tools to communicate with their relatives and the rest of the world. Following the armed conflict, Libya was forced to start from scratch in building up the country's infrastructure and services [1]. One of the difficulties is the reconstruction and the policy problems involved in redeveloping the education system because most of the educational institutions and universities in the affected areas have lost their infrastructure and resources. Implementing any type of process that involves change and alterations to how people work can present difficulties for an organisation. Estimates have shown that up to 70 percent of the cost of implementing a major organisational change has been linked to managing employee behavior during the transition [2]. The process of transforming an organisation's objectives into strategies that deliver lasting, sustainable change is, to a large extent, dependent on how institutions approach changing everyday processes. When there are major shifts in the processes faculty and staff are relied upon to do their jobs on a daily basis, and senior administration must fully endorse and engage in the planning, development, and launch of the initiative for it to be successful.

This paper presents the trends and policy issues of elearning implementation in Libyan universities (LUs) through a modern model of SWOT analysis to reflect the

Manuscript received September 3, 2013; revised October 20, 2013.

The authors are with University of Huddersfield, School of Computing and Engineering, Queensgate, Huddersfield HD1 3DH, United Kingdom (e-mail: Thuraya.Kenan@hud.ac.uk). evolution of the current implementation strategies. It is obvious that some universities have managed to implement successfully e-learning systems despite the drawbacks faced due to economic, political and social difficulties existing in Libya. The model analyses the actual stage of e-learning implementation in several LUs to offer appropriate suggestions for improving and guiding the implementation team towards the correct performance of e-learning in Libyan HE institutions.

\section{ThE PROGRESSION OF E-LEARNING IMPLEMENTATION IN LIBYAN UNIVERSITIES FROM 2009 TO 2013.}

SWOT is an acronym for Strengths, Weaknesses, Opportunities and Threats. The 'opportunity' and 'threat' should both focus on the possible future of an analysed situation. "The people who use SWOT might conclude that they have done an adequate job of planning and ignore sensible things such as defining the firm's objectives for alternate strategies" [3]. So it is important to consider various solutions after examining the results of SWOT analysis. The SWOT method can be used during the design, development and implementation stages of any project. It is also a convenient tool for the evaluation stage in order to have an initial idea of the future consequences.

Kenan [4] designed a questionnaire in 2009 (Quest.2009) to identify the challenges experienced by 63 teachers, students and technical staff when using technology in Tripoli University. A second questionnaire was designed in 2013 (Quest.2013) in order to check if the respondents confirmed the trends and the policy issues of using elearning in LUs. A number of 28 teachers, 39 students and 10 technical staff completed this questionnaire. They could express their personal opinions about other challenges they were facing when using e-learning and ICT for the educational purposes. Here are the conclusions of the comparison between the answers to Quest.2009 and Quest.2013.

TABLE I: PERCEPTIONS OF RESPONDENTS OF COMPUTER USAGE IN 2009\&

\begin{tabular}{|l|c|c|c|c|}
\hline \multicolumn{1}{|c|}{$\begin{array}{c}\text { Computer } \\
\text { usage }\end{array}$} & $\begin{array}{c}\text { People Quest. } \\
\mathbf{2 0 0 9}\end{array}$ & $\begin{array}{c}\mathbf{\%} \\
\mathbf{2 0 0 9}\end{array}$ & $\begin{array}{c}\text { People Quest. } \\
\mathbf{2 0 1 3}\end{array}$ & \begin{tabular}{c}
$\mathbf{2 0 1 3}$ \\
\hline Every day
\end{tabular} \\
\hline $\begin{array}{l}\text { 3-4 times every } \\
\text { week }\end{array}$ & 22 & $34.9 \%$ & 11 & $14.3 \%$ \\
\hline $\begin{array}{l}\text { 1-2 times every } \\
\text { week }\end{array}$ & 25 & $39.6 \%$ & 4 & $5.2 \%$ \\
\hline Rarely & 3 & $4.7 \%$ & 0 & $0 \%$ \\
\hline Never & 0 & $0 \%$ & 0 & $0 \%$ \\
\hline The total & $\mathbf{6 3}$ & $\mathbf{1 0 0 \%}$ & $\mathbf{7 7}$ & $\mathbf{1 0 0 \%}$ \\
\hline
\end{tabular}




\section{Strength Points}

All respondents have been using the computers for various educational activities as shown in Table I.

Internet access has been active since 2000 in most LUs [5] and Table 1 shows there has been an increase in the interest in technology. This is because LUs are spending more of their budgets on providing their ICT.

\section{A. Opportunity Points}

The respondents chose the following benefits of using elearning from a list of options provided in the questionnaire as shown in Table 2. Qu.2009 \& Qu.2013 differed in that the question were changed to multi-options.

TABLE II: PERCEPTIONS OF RESPONDENTS ABOUT E-LEARNING BENEFITS IN $2009 \& 2013$

\begin{tabular}{|c|c|c|c|c|}
\hline Benefits & $\begin{array}{c}\text { People } \\
\text { Quest. 2009 }\end{array}$ & $\begin{array}{c}\mathbf{2 0 0 9} \\
\text { Quest. 2013 }\end{array}$ & $\begin{array}{c}\text { People } \\
\mathbf{2 0 1 3}\end{array}$ \\
\hline $\begin{array}{c}\text { Language skills } \\
\text { acquired }\end{array}$ & 37 & $58.7 \%$ & 68 & $88.3 \%$ \\
\hline IT skills acquired & 10 & $15.9 \%$ & 73 & $94.8 \%$ \\
\hline Time management & 7 & $11.1 \%$ & 51 & $66.2 \%$ \\
\hline $\begin{array}{c}\text { Comfortable } \\
\text { education }\end{array}$ & 6 & $9.5 \%$ & 36 & $46.7 \%$ \\
\hline New method & 3 & $4.8 \%$ & 27 & $35.1 \%$ \\
\hline The total & $\mathbf{6 3}$ & $\mathbf{1 0 0 \%}$ & Multi-option question \\
\hline
\end{tabular}

Even though the method of question had changed, it was clear that there was acquisition of new languages and IT skills.

\section{B. Weaknesses}

The respondents chose the following barriers to elearning implementation ahead of Libyan universities LU as shown in Table III.

TABLE III: PERCEPTIONS OF RESPONDENTS ABOUT THE BARRIERS OF ELEARNING IMPLEMENTATION IN 2009\& 2013

\begin{tabular}{|c|c|c|c|c|}
\hline Barriers & $\begin{array}{c}\text { People Quest. } \\
2009\end{array}$ & $\begin{array}{c}\% \\
2009\end{array}$ & $\begin{array}{c}\text { People Quest. } \\
2013\end{array}$ & $\begin{array}{c}\% \\
2013\end{array}$ \\
\hline $\begin{array}{l}\text { Technological } \\
\text { barriers }\end{array}$ & 22 & $34.9 \%$ & 25 & $32.5 \%$ \\
\hline $\begin{array}{l}\text { Mismanagement } \\
\text { barriers }\end{array}$ & 18 & $28.6 \%$ & 31 & $40.4 \%$ \\
\hline Cultural barriers & 13 & $20.6 \%$ & 12 & $15.5 \%$ \\
\hline $\begin{array}{l}\text { Others: such as } \\
\text { cost, etc. }\end{array}$ & 10 & $15.9 \%$ & 9 & $11.6 \%$ \\
\hline The total & 63 & $100 \%$ & 77 & $100 \%$ \\
\hline
\end{tabular}

The majority of respondents to Quest 2009 considered that technological barriers were important while $40.4 \%$ of respondents to Quest 2013 chose barriers due to mismanagement.

Mismanagement and other reasons: the social impact after the war; lack of a general strategy of education linking the different stages of study, with a consequent difficulty in accepting E-learning [6]; lack of common regulations or standards for E-learning in a country which does not generally approve of such methodology; disapproval from the Ministry of Education for E-learning courses [7]; difficulty in securing accreditation collaboration; the management-corruption and lack of cross-institutional collaboration [8].

Technological barriers include: insufficient network and systems infrastructures; weaknesses of E-learning development in HE institutions; difficulties in overcoming initial implementation problems; lack of experience in using technology; lack of provision of robust Internet access; lack of specific student services [9].

Cultural barriers consist of: unfamiliarity with the Internet and related technologies resulting in lack of appreciation and understanding of E-learning and its benefits; opposition to the adoption of the necessary educational changes (e.g. self-regulation, student centred) required for successful E-learning [10].

\section{Threats}

The answers given by the respondents show that the following categories display resistance to e-learning implementation in Libyan HE as shown in Table IV.

TABLE IV: PERCEPTIONS OF THE E-LEARNING RESISTORS IN 2009\& 2013.

\begin{tabular}{|c|c|c|c|c|}
\hline $\begin{array}{c}\text { Resistance to } \\
\text { e-learning }\end{array}$ & $\begin{array}{c}\text { People } \\
\text { Quest. 2009 }\end{array}$ & $\begin{array}{c}\mathbf{\%} \\
\mathbf{2 0 0 9}\end{array}$ & $\begin{array}{c}\text { People } \\
\text { Quest. 2013 }\end{array}$ & $\begin{array}{c}\mathbf{2 0 1 3} \\
\mathbf{2 0 1 3}\end{array}$ \\
\hline $\begin{array}{c}\text { Academic staff } \\
\text { (teachers) }\end{array}$ & 18 & $28.6 \%$ & 40 & $51.9 \%$ \\
\hline Training staff & 14 & $22.2 \%$ & 59 & $76.6 \%$ \\
\hline $\begin{array}{c}\text { Government } \\
\text { team }\end{array}$ & 13 & $20.6 \%$ & 22 & $28.5 \%$ \\
\hline Leadership & 10 & $15.9 \%$ & 68 & $88.3 \%$ \\
\hline $\begin{array}{c}\text { Students and } \\
\text { scholars }\end{array}$ & 8 & $12.7 \%$ & 21 & $27.2 \%$ \\
\hline The total & 63 & $100 \%$ & \multicolumn{3}{|c|}{ Multi-option question } \\
\hline
\end{tabular}

These results of Strength, Opportunity, Weakness and Threats reflect the SWOT analysis for the main aspects, which should be considered when developing more effective e-learning implementation strategies. It also presents the reflections of the students, lecturers, and technical staff on the trial implementation.

Also, Rhema and Miliszewska [10] undertook a SWOT study about the e-learning implementation at the Data Analysis Department and identified that technological and cultural barriers are hindering the e-learning implementation in the University of Gharian-Libya.

Artemi and Ajit [11] emphasised that many people perceive technological barriers as being essential in the elearning implementation because people need access to modern technology in order to improve the quality of the teaching and learning processes. SWOT analysis is an essential step to analyse various factors before implementing an e-learning solution at any institution, because the success or failure of an e-learning initiative will be directly related to the policy issues that underpins it [12].

\section{SWOT MODEL}

The success or failure of an e-learning initiative is directly related to the quality of strategic thinking that underpins it and SWOT analysis should be performed before implementing an e-learning solution at any institution. It is thus important to have an e-learning strategy in place before beginning the implementation process.

This SWOT model is based on the personal experiences of the authors who have studied at Tripoli University and then became lecturers at the same university. It is also based on the study of the latest results related in 2009 to recent 
SWOT analyses in 2013 of LUs performed by other authors such as Artemi and Ajit [11]], Rhema and Miliszewska [10] (see Table V).

TABLE V: MODERN SWOT ANALYSIS OF E-LEARNING IMPLEMENTATION IN LIBYAN UNIVERSITIES

\begin{tabular}{|c|c|}
\hline Strength points: & Weakness points \\
\hline $\begin{array}{l}\text { 1. The government policy system changed } \\
\text { on October } 2011 \text { when it was officially } \\
\text { declared the liberation of Libya. So the } \\
\text { new government looks to support the } \\
\text { LUs in a number of ways. } \\
\text { 2. The proliferation of digital technology } \\
\text { because the majority of people are } \\
\text { using computers and social media } \\
\text { channels to communicate with each } \\
\text { other. } \\
\text { 3. An annual increase the student numbers } \\
\text { in the LUs. } \\
\text { 4. The need to eliminate the } \\
\text { administrative corruption aspects. } \\
\text { 5. Implement modern and efficient } \\
\text { management structures in the LUs. } \\
\text { 6. Libya has a strategic geographical } \\
\text { location in Africa. The people from } \\
\text { Niger, Sudan, Mali and Chad could use } \\
\text { the e-learning packages developed by } \\
\text { the companies situated in Libya. Also } \\
\text { people living at long distances from the } \\
\text { main Libyan universities (such as } \\
\text { Awbari, Ghat, Aljawf, Murzuq and } \\
\text { Alkoofra) could complete their courses } \\
\text { by distance learning. }\end{array}$ & $\begin{array}{l}\text { 1. Lack of training courses } \\
\text { for the students, technical } \\
\text { and academic staff. } \\
\text { 2. Lack of technological } \\
\text { support and periodic } \\
\text { maintenance of computers. } \\
\text { 3. Lack of online library } \\
\text { catalogues in the LUs } \\
\text { 3. Mismanagement and } \\
\text { corruption. } \\
\text { 4. Users' lack of awareness } \\
\text { and fear of negative } \\
\text { consequences of using } \\
\text { technology in the education } \\
\text { processes. } \\
5 \text { Post-war chaos that } \\
\text { pervades all sectors of } \\
\text { Libyan society and } \\
\text { economy. }\end{array}$ \\
\hline Opportunity points & Threat points \\
\hline $\begin{array}{l}\text { 1. Official recognition of education } \\
\text { certificates holders of e-learning or } \\
\text { distance education. } \\
\text { 2. Create new business strategies to } \\
\text { attract students from other African } \\
\text { countries that still lack the basics of e- } \\
\text { learning in their Higher Education } \\
\text { Institutes. } \\
\text { 3. Reduce the migration of skilled and } \\
\text { intelligent people from Libya. } \\
\text { 4. Create techno-education competitive } \\
\text { environment with the neighbouring } \\
\text { countries. } \\
\text { 5. Development of new courses in } \\
\text { foreign languages (English, French, } \\
\text { etc.) in LUs. } \\
\text { 6. Gradual change of culture including } \\
\text { more acceptances to of e-learning } \\
\text { systems. } \\
\text { 7. Geographical position of Libya in } \\
\text { Africa plays strategic role in the } \\
\text { successful and the necessary need to } \\
\text { implementation of e-learning system in } \\
\text { LUs. }\end{array}$ & $\begin{array}{l}\text { 1. Numerous barriers related } \\
\text { to e-learning systems } \\
\text { implementation. } \\
\text { 2. Preference of using only } \\
\text { academic traditional } \\
\text { methods in education. } \\
\text { 3. Lack of support from the } \\
\text { government. } \\
\text { 4. Increased migration of } \\
\text { skilled and intelligent } \\
\text { people from Libya. }\end{array}$ \\
\hline
\end{tabular}

An e-learning initiative must be tied to the institution's core business to ensure that that the quality of the educational processes is enhanced [11]. The review recommends that the institutions should start working hard on minimising the weaknesses (such as poor English skills of students as well as instructors, lacking ICT infrastructure, lack of e-learning know-how, etc.). Also, the use of blended learning approach will enable the academics and students to have a smooth transition during the e-learning systems implementation [12].

SWOT analysis should help the decision-makers at departmental level to decide on opportunities with respect to e-learning implementation; also, to choose the appropriate policy issues for it: improvement of the learners' knowledge, learning outcomes, efficiency of the teaching and learning processes and reduction of costs.

\section{POLICY ISSUES AND ACCESSIBILITY CHALLENGES}

There are still many challenges to address on the successful policy and suitable strategy of e-learning implementation. These challenges are mainly pedagogical, technological, and attitudinal [13] as follows:

\section{A. Lack of Training Courses and Languages Skills}

Although most LUs provide each faculty member with a personal computer, a significant percentage of faculty members are still computer illiterate, and it is reasonable to suppose there will be resistance from those members towards any attempt to adopt an e-learning model in their discipline within the university. Also, some of faculty members have difficulty with the English language.

\section{B. Lack of Interests by University Administrations Regarding the Possibilities of e-Learning Is also a Real Challenge}

Staff teams in the Arabic universities fear that e-learning that would abruptly shift traditional education into a new pedagogical venture with which lecturers and policymakers are not sufficiently familiar.

\section{Rigid Learner-Lecturer Relation}

If Libya had been a strong power structure governing the relationship between a learner and a lecturer, any learner may feel subservient to the lecturer and this could prove a problem when the learner is asked to discuss his/her views freely with the lecturer.

\section{Lack of Arabic Learning Tools and Applications for e- Learning Courses}

This will be a serious challenge in implementing elearning into LUs, where the Arabic language is the teaching language. But even for the science-based colleges where English is the official teaching language, the lack of Arabic learning applications might cause a problem for a large proportion of students.

\section{E. Highest Load on the Academic Staff}

The teaching load in Libyan universities is typically large, for example: the average number of teaching hours for academic staff is 24 hours per week, and Libyan universities have not yet established an academic research tradition [14]. Thus, even professors find it difficult to find the time for research activity and educational development. The Libyan business executive survey/global competitiveness report (LBES/GCR) ranks Libya $97^{\text {th }}$ out of 111 countries in university/industry research collaboration [9]. Some academic staff does undertake extra activities such as writing and publishing, e.g. text books, to increase their income.

\section{F. Lack of Official Recognition by the Qualifications of Online Studies}

Teaching and learning are the cornerstones of any HEI. However, maintaining the quality of such processes is a continuous challenge. There is no official recognition in Libya for distance or online learning as a valid mode of education and most LUs have not appointed staff members 
with formal qualifications in either distance learning or online learning [12].

Once the key players are committed to the implementation process, quality control and measurable outcomes must be considered as part of implementation [15] So the SWOT analysis should look at the main policy issues, the strategy trends (such as the economic situation), social impacts and technological developments.

\section{CONCLUSIONS AND SUGGESTIONS FOR THE IMPLEMENTATION OF E-LEARNING STRATEGY IN THE INSTITUTIONS IN LIBYA}

Libyan universities could take many benefits from combining the active learning methods with suitable policy or accessibility into e-learning implementation [8]. Both active learning and e-learning encourage students to use numerous sources of knowledge, and persuade them to integrate and employ information efficiently.

Libya must match and compete with the standards of other countries' universities strategies. This goal is part of Libya's move towards a knowledge society for which ICT is considered a prerequisite to make decisions about technology issues before the implementation of practical elearning systems aiming to reduce the investment of time, effort and money.

\section{A. Suggestions to Improve the Learners' Knowledge and Understanding}

LUs should hire an adequate number of support staff to be responsible for administrative duties and take this heavy burden away from academic staff. Support staff may be utilised to check regularly that the course content has been updated. The lecturers should share with the learners their availability schedule to let them know when to expect a response from a lecturer. A backup plan should be put in place in cases where the lecturers will be out of reach or unavailable for a long period and staff members should be provided for support. It would be beneficial for the elearning policies to have the course content available in Arabic and English languages. As the country has not yet reached a stage where most of the learning materials are home developed, it might be premature to suggest course content to be only in Arabic, as English is considered the medium of instruction.

\section{B. Suggestions for the Universities in Implementation of Policies}

The change policy system must be gives dedication and strong motivation to all the decision makers; and the employees should be encouraged to attend internal and external workshops so the software and hardware packages and the relevant ICT support can be updated continuously [12]. To be successful E-learning should have the affirmative support of senior management and a fixed budget that has been set aside to maintain and develop the facilities. Also, the course lecturers and developers should attend regular training courses related to the new hardware, software and learning management packages. The Libyan learners have different educational experiences based on the geographic location of their colleges and universities: the learners from rich areas (such as Tripoli Town Centre) have access to the latest state-of-the-art technology [13]; learners from suburban areas have a lifestyle similar to more developed countries, and learners from areas such as AlKoofra city have third world experiences and never saw or used a computer until they reach HE. Therefore, the mindsets and the attitudes towards learning of such diverse learners should be taken into consideration.

\section{Suggestions for Governmental Policies in the LUs}

The Libyan government should give more support to the LUs that have shown success in the implementation and management of e-learning so these institutions will feel encouraged sharing their success with other institutions. More coordination and resource sharing between different LUs could be of general benefit. Government departments of Higher Education Ministry have all responsibility to sponsor development of technologies in LUs that will produce a workforce that is competent in technologies.

\section{REFERENCES}

[1] A. Rhema and I. Miliszewska, "The potential of e-learning in assisting post-crisis countries in re-building their higher education systems: the case of Libya," Issues in informing Science and information technology, 2012, vol. 9, pp. 149-160.

[2] J. Dyche, The Crm Handbook, Boston, MA. Addison-Wesley Pearson Education, Education Economics, 2002, vol. 9, no. 2, pp $139-144$

[3] J. Scott, "The value of formal planning for strategic decisions," Strategic Management Journal, vol. 3, pp. 197-211, 1982.

[4] T. Kenan, "The barriers of e-learning in higher education in Libya," Published MSc Dissertation, 2009, University of Salford, UK.

[5] M. Porter and D. Yegin, "National economic strategy: an assessment of the competitiveness of the Libya," The general planning council of Libya, 2006, Cera, UK

[6] T. Kenan, C. Pislaru, and A. Elzawi, "Comparing the impact of Elearning and ICT in higher education institutions in Libya and United Kingdom," in Proc. ICEIC 2011, Florida, USA, 2010, pp. 162-173.

[7] A. Elzawi and S. Wade, "Barriers to ICT adoption in quality of engineering research in Libya: how to bridge the digital divide?" in Proc. The Queen's Diamond Jubilee Computing and Engineering Annual Researchers' Conf., CEARC'12. UK: University of Huddersfield, 2012, pp. 98-103.

[8] T. Kenan and C. Pislaru, "Challenges related to the implementation of e-learning in higher education institutions in Libya," in Proc. The Queen's Diamond Jubilee Computing and Engineering Annual Researchers' Conference 2012, Huddersfield: University of Huddersfield, 2012, pp. 116-122.

[9] A. Elzawi, T. Kenan, S. Wade, and C. Pislaru, "Bridging the Digital Divide and Enhancing the Quality of Engineering Research in Libyan Universities," in Proc. 6th Conference on Quality in Middle East, Hamdan Bin Mohammed University, 2012, Dubai.

[10] A. Rhema and I. Miliszewska, "Reflections on a Trial implementation of an e-learning solution in a Libyan University," Issues in informing Science and information technology, vol. 8, pp. 16, 2011.

[11] M. Artemi and K. Ajit, "A SWOT analysis of e-learning model for the libyan educational institutions," in Proc. The 3rd National Conference of Basic Science, Aljabal-Algharbi University, 2009, Gharian, Libya.

[12] T. Kenan, C. Pislaru, and A. Elzawi, "Novel SWOT Analysis of Elearning Implementation in HE Institutions in Libya," International Journal on E-learning (IJEL): Association for the Advancement of Computing in Education (AACE), 2013.

[13] T. Kenan, C. Pislaru, and A. Elzawi, "Analysing the effectiveness of e-learning based on national and international cultures and approaches to pedagogy," in Proc. 17th UKAIS Conf. on Information Systems, March 2012, UK, 2012, New College, Oxford University.

[14] A. Elzawi and J. Underwood, "How higher engineering researchers in libya perceive the use of internet technology," in Proc. The International Arab Conf. on Information Technology (ACIT'2010), University of Garyounis, Benghazi, Libya, 2010, pp. 89-98. 
[15] T. P. Jan, R. Gary, and Gentry, "Developing an e-learning strategy in higher education," Western Governors University, USA: Emerald Group Publishing Limited, 2009.

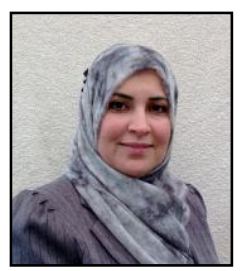

Thuraya Kenan became a member (M) of Association for the Advancement of Computing in Education (AACE) with start 2013, the Digital Library for Education \& Information Technology (EdITLib) in 2012, and Institution of Engineering and Technology (IET) in 2011. She obtained BSc in Electronic\& Computer Engineering from University of Ezawia, Faculty of Sabratha, Libya in 1998. Then she received MSc in IT Management from University of Salford, UK in 2009. Mrs. Kenan is currently a PhD researcher in the School of Computing and Engineering at the University of Huddersfield, UK. She is the author of six conference papers and two journal papers and her current research explores issues in the fields of e-Learning design, methodologies, policy issues, standards; social impact and cultural issues in e-Learning; virtual learning environments; Internet and emerging technologies; audio and video technologies for e-Learning; assessment and feedback for online courses; using technology for modern Higher Education courses; innovative curriculum in E-Learning; instructional design for E-Learning and knowledge management in E-Learning.

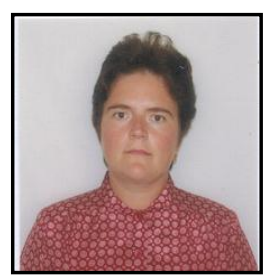

Crinela Pislaru became a member (M) of IEEE in 1999. She obtained MEng (Distinction) degree in Electrical and Electronic Engineering from Transilvania University Brasov, Romania in 1991 She received her $\mathrm{PhD}$ in Control Engineering 2001 and MSc in Multimedia and E-learning from the School of Education and Professional Development, University of Huddersfield in 2008 She is currently a senior lecturer in the Engineering and Technology department at the University of Huddersfield, UK. She is the author of over 100 refereed publications and reviewer for several internationally leading journals. Dr. Pislaru's pedagogical research is focused on the underpinning knowledge and behaviours needed for academic staff to work across boundaries and develop intelligent E-learning technology and interactive E-learning systems. They should attract and engage industry and successfully guide and support the development of a sustainable engineering and informatics workforce able to learn and operate in a digital age.

Dr. Pislaru is a fellow of Higher Education Academy (FHEA) and Leader of Pedagogical Research group within the School of Computing and Engineering at the University of Huddersfield, UK. She is the Chair of West Yorkshire network of the Institution of Engineering and Technology (IET) and Member of UK Engineering Council and ASPE (American Society for Precision Engineering). Dr Pislaru is a reviewer for ten internationally leading journals and Engineering and Physical Science Research Council (EPSRC) projects and external examiner for international institutions.

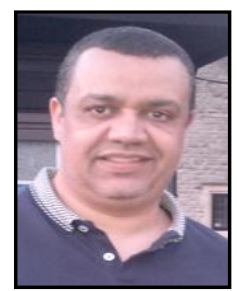

Abdussalam Elzawi became a member (M) of Association for the Advancement of Computing in Education (AACE) with start 2013, the Digital Library for Education \& Information Technology (EdITLib) in 2012, and Institution of Engineering and Technology (IET) in 2011. He obtained BSc in Science from University of Ezawia in 1989. Then he received MSc in IT Management from the University of Salford, UK in 2008. Mr Elzawi is currently a PhD researcher in the School of Computing and Engineering at the University of Huddersfield, UK. His research focuses on digital libraries and repositories, learning resources and environments; ICT applications; open technologies; the influences of the digital gap, Internet and emerging technologies, knowledge management and E-learning in Libyan Higher Education Institutions. 